\title{
THE IMPACT OF DIGITAL TECHNOLOGY UTILIZATION IN THE TRADE SECTOR ON ITS PRODUCTIVITY, LABOR AND ECONOMIC GROWTH
}

\author{
Dampak Pemanfaatan Teknologi Digital pada Sektor Perdagangan Terhadap \\ Produktivitas, Tenaga Kerja dan Pertumbuhan Ekonomi
}

\author{
Muhammad Rizal Taufikurahman ${ }^{1}$, Ahmad Heri Firdaus ${ }^{2}$ \\ ${ }^{1}$ Trilogi University, JI.Trilogi (d/h STEKPI) No.1 TMP Kalibata, Jakarta 12760,DKI Jakarta, Indonesia \\ ${ }^{2}$ Institut Bisnis dan Informatika Kwik Kian Gie, Jl. Yos Sudarso Kav 87 Sunter, \\ Jakarta 14350, DKI Jakarta, Indonesia \\ Email: mrizalt@trilogi.ac.id
}

Naskah diterima: 18/09/2018; Naskah direvisi: 24/03/2019; Disetujui diterbitkan: 04/11/2020; Dipublikasikan online: 18/12/2020

\begin{abstract}
Abstrak
Kehadiran ekonomi digital sebagai bagian dari revolusi industri 4.0 yang telah membuka peluang baru dalam bidang perdagangan dan menjembatani kepentingan produsen, konsumen, dan pasar tanpa dibatasi ruang dan waktu. Tujuan penelitian ini adalah menganalisis dampak pemanfaatan teknologi digital pada sektor perdagangan terhadap produktivitasnya, penyerapan tenaga kerja dan pertumbuhan ekonomi. Metode analisis yang digunakan adalah metode analisis model Computable General Equilibrium (CGE) dinamik. Hasil analisis menunjukkan digitalisasi di sektor perdagangan meningkatkan jumlah outputnya sebagai produktivitas jangka pendek dan panjang. Adapun dampak terhadap penyerapan tenaga kerja di perkotaan dan pedesaan menurunkan jenis pekerjaan tertentu pada periode analisis terutama tenaga kerja terampil rendah. Selanjutnya dampak terhadap GDP riil meningkat pada periode analisis. Kebijakan yang direkomendasikan adalah perlu perbaikan akurasi dan validitas database produk-produk yang kompetitif, strategi antisipatif untuk tenaga kerja yang terdistrupsi, pelayanan perizinan akses semakin mudah, optimalisasi aplikasi teknologi digital dalam tata kelola perdagangan, dan perbaikan sarana prasarana informasi dan teknologi.
\end{abstract}

Kata Kunci: Teknologi Digital, Produktivitas, Tenaga Kerja, Pertumbuhan Ekonomi

\begin{abstract}
The presence of a digital economy as part of the industrial revolution 4.0 has opened up new opportunities in trade and bridged the interests of producers, consumers, and markets without being constrained by time and space. The study aims to analyze the impact of digital technology utilization on the trade sector on its productivity, labor, and economic growth. The analysis method used is the Dynamic Computable General Equilibrium (CGE) model. The analysis results show that digitalization in the trade sector increases output as productivity in the short and long term. The impact on labor in urban and rural areas reduces certain types of work in the analysis period, especially low skilled labor. Furthermore, during the analysis period, the impact on real GDP increases. The recommended policy is to improve the accuracy and validity of competitive products' database, anticipatory strategies for labor that have disrupted, easier access licensing services, optimization of digital technology applications in trade governance, and improvement of information and technology infrastructure.
\end{abstract}

Keywords: Digital Technology, Productivity, Labor, Economic Growth

JEL Classification: F12, F13, F15 


\section{INTRODUCTION}

Information and communication technology development often inquired rapid digital technology and has an impact on almost industrial sectors. This change certainly needs regulations to maximize the users' benefit of using digital technology. These regulations must be in line with the needs of all industrial and trade sectors and service stakeholders. These policies and regulations also require a better understanding of the values that exist in Indonesian culture.

These conditions deliver some information to create a market. The digital economy's presence as part of the industrial revolution 4.0 is the focus of world attention because it has brought significant changes in the current trading pattern. Besides, the digital economy has also opened up new opportunities in the field of trade.

The rapid development of using the information or digital technology in digitalization 4.0 has become a driver of digitalization changes in production and consumption factors related to economic activity and encouraging economic growth. Changes in the production aspect using information technology in recent years are happening in some sectors, and the utilization is very rapid, including in the trade sector (Romer, 2011)

The growing development of digital economic products in Indonesia, such as the trade sector, requires regulatory tools to regulate and develop the sector. At present, digital economic products have been commonly used in the form of digital transactions such as using electronic money, financial technology products, online-based trading (ecommerce), and others.

The rapid development of digitalization in the global trade sector has led to a new digital economy phenomenon. Manual economic changes towards the digital economy impact technological disruption, one of them. If it is not handled seriously and anticipated, this condition can be a serious problem and will affect other important sectors.

The relationship between the digitalization of information technology and economic development has encouraged broadband networks to be even greater. In addition to having an impact on various economic transactions, it will also impact on Gross Domestic Growth (GDP). Finally, encouraging the use of information and communication or digital technology is a necessity. 
The digital technologies have changed the way business-to-business firms act in business markets, central to economies, changes economic activities, and how they sell value new requirements to a firm's capabilities (Ghandi, et.al, 2018; Azmeh, et. al; and Goldfarb \& Tucker, 2019; and Syam \& Sharma, 2018). Ahmedov (2020) explains that the impact of digitalization on international and global trade can certainly be controversial. The digitization and digitalization of business-to-business firms' business models have recently attracted a great deal of attention (Ritter and Pederson, 2020).

E-Commerce in Indonesia is more or less certainly related to the development of e-commerce in developed countries (Yadiati \& Meiryani, 2019), the new possibility of combining high tech with low wages propelled the rapid industrialization of a handful of developing nations (Baldwin, 2016) and with the growing importance of the internet, digital trade, or electronic commerce has become a key issue in the trade regulation (Henry, 2018). For instance, Ross (2017) argues that digital and digitized are two very different organizational phenomena. Digital technology in trade development has strong spread effects due to the existing work in the information sector, and technology creates three jobs in other sectors. Another impact of information technology development is the existence of more equitable social development and a more transparent and efficient public sector (Gryseels et al., 2016).

The important aspects of information and communication technology are currently happening in a country's economic progress. However, if judging in terms of readiness, it turns out that Indonesia still has not utilized the development of information technology to support the progress of other sectors.

According to Bilbao-Osorio (2014) in the Global Information Technology Report (GITR) on the information and communication technology sector or the digital sector globally, Indonesia ranks 64 th out of 148 countries assessed on its Network Readiness Levels. In Southeast Asia, Indonesia is ranked number fourth under Singapore, Malaysia, and Brunei Darussalam.The use of information and communication technology or the digital sector in Indonesia indicated that the number of internet users is only 88.1 million people from a total population of 254 million. 
That is, new internet penetration is $34.9 \%$ of the total population (APJII, 2018). Furthermore, almost half of the internet users are in Java, which accounted for 52 million users. Followed by Sumatra for 18.6 million, Sulawesi 7.3 million, Nusa Tenggara, Papua, and Maluku for 5.9 million, and Kalimantan for 4.2 million users.

This achievement has led to an increase in productivity in sectoral performance as an economic structure. Parlindungan (2015) stated that it had increased productivity in the trade sector through two major parts: improving the non-oil and gas manufacturing sector's performance and increasing the efficiency and effectiveness of the national service goods distribution sector. Based on this phenomenon, the study aims to analyze the impact of digital technology utilization in the trade sector on its productivity, labor, and economic growth.

\section{METHODS}

This research's data type is secondary data, which is used to construct the primary data analyzed in this research. It consists of the newest data of Input-Output table (I-O), Social Accounting Matrixes (SAMs), and other relevant data. The analysis model used in this research is the CGE model framework.

In constructing the database model, this study uses the latest national-level data, i.e., IO Table 2010, SNSE Table 2008, SAKERNAS 2010, and SUSENAS 2010 (BPS, 2010; 2015). The database is intended to be updated so that the model can be accommodated by various changes in the Indonesian economy that lasts dynamically until the year of analysis. The data are collected from various publications, such as the Central Statistics Agency (BPS), Ministry of Agriculture, Ministry of the Trade, Bank Indonesia, Ministry of Finance, Ministry of PPN/ Bappenas, and other relevant institutions.

The economic analysis is described through an economic model using certain assumptions. One of them is the market for all products (both input and production output), is a perfect competitive market (perfect competitive markets). An economy under perfect competitive market assumptions if there are many homogeneous goods, both final consumer goods and production input goods. In addition, each type of goods has its equilibrium price, and there are no transaction and 
transportation costs, and each individual (producer and consumer) has perfect information about the market and its goods.

This concept can be entirely explained by using the Computable General Equilibrium (CGE) model. A computable general equilibrium (CGE) model is a type of economic model that can reveal information on the whole economy and detailed industries. CGE modeling appeared in the early 1980s and is now widely used for economic analysis and policy assessment (Meng \& Siriwardhana Me, 2017)

Additionally, the production possibility curve can be used to find out how the relationship between output and input. Using the CGE model in the analysis of the trade sector in Indonesia is necessary to provide a comprehensive picture of increasing trade sector productivity.

According to Dixon \& Rimmer $(2002 ; 2005)$, the general equilibrium (GE) theory is a formalization of the fact that markets are interrelated. Changes to supply and demand conditions in a market generally have repercussions (linkages) in conditions of equilibrium prices in other markets. Walmsley et al. (2015) explain that the CGE model attempts to apply the GE theory as an empirically oriented analysis tool to analyze issues related to allocating resources to a market mechanismbased economy.

The Computable General Equilibrium (CGE) economic model itself is a system that contains a set of non-linear equations consisting of $n$ variables and $n$ equations (Dixon \& Rimmer (2002; 2016)). The GEMPACK program can solve the system/equation using an inverse matrix. In this program, we use a linearized equation system. According to Dixon et al. (2013; 2014; 2016; and 2018), it can also correct linearization errors so that the solution obtained will be the same as non-linear calculations.

The data processing used the GEMPACK Program to solve problems in the general equilibrium economic model. Furthermore, this study modified the CGE model with INDOF (Oktaviani, 2001) and ORANIGRD (Horridge, 2002). Moreover, it is also combined with AGRIFISCGE (Taufikurohman, 2004) to provide elasticities number and some model parameters. Furthermore, the constructing CGE model is a dynamic CGE model.

The modeling carried out in the research follows the INDOF model procedure (Oktaviani, 2001). This model 
is still a comparative static model. Because in this research, forecasting certainly needs to do dynamic recursive modelling (Dixon and Rimmer, 2002). In order to make this model dynamic recursive, adding some special blocks is dynamic. That is in the form of real wage adjustments, labor mobility, and capital accumulation. The addition of the equation was adapted from the ORANIGRD model (Horridge, 2002).

In analyzing several parameters and elasticity's productivity, the model used is taken from the AGRIFISCGE model (Taufikurohman, 2012). In addition to the several parameters of commodity substitution elasticity in the model resulting from the estimation of the econometric model's use, the variables and indicators in the model are updated including those in the trade sector. Moreover, several other elasticity figures have also been updated, especially in supporting productivity analysis.

Thus, the modeling used in this analysis adapts several models to answer the phenomenon of productivity in the use of technology. It is especially for the trade sector (Zahniser et al., 2012).

The argument of using the dynamic model is explicitly shows changes to each variable at any given time (generally annual). Dynamic models like this are more realistic, but are also more difficult to design and solve. Especially this study want to see the impact of using information technology in trade.

Although in dynamic models require many requirements, such as predictions of changes for each exogenous variable (Wittwer, 2017). The dynamic elements of this type of model can be in the form of partial adjustment processes or in the form of accumulated relations such as capital and investment, foreign debt and trade deficits.

The dynamic CGE model is also a type of dynamic model that can be solved successively (per time period). This type of model assumes that economic behavior is only determined by current and past conditions. If the behavior of economic agents is determined by a condition in the future, the CGE model must be solved for all time periods simultaneously.

This type of model is referred to as a multi-period dynamic CGE model. Among these last types of CGE models, there is a stochastic CGE model that explicitly adopts the assumptions of uncertainty from the future (Wittwer, 
1999). Such is the reason why using dynamic models in this study (Wittwer, 2017).

Through this model, the impact of the policy determined from year to year can be known. The dynamic element in the model is shown by capital accumulation and labor growth every year (Rowe, 1987). Giesecke \& Madden (2013) reinforce the opinion that CGE model has become a standard input to policy deliberations in a growing number of countries. The analytical method used is a general equilibrium (CGE) economic balance model. This model is used to see the impact of changes in general economic variables on income distribution in a various household, industrial sectors, and several macroeconomic indicators. The CGE model of a national economy is a system of equations that reflects all economic actors' behavior, namely the behavior of consumers and producers and the condition of clearing markets for goods and services in the economy.

The simulation performed for the approach the utilization of technology digitization is the amount of government and private expenditure budget in investing in information technology infrastructure (Rose et al., 2017). Beside it, a computer general equilibrium model
(CGE) with detailed and disaggregated industry, product and factor markets has great potential to quantify the general equilibrium effects (Freebairn, 2017)

The CGE model's closures augment technical change as an exogenous variable for the trade sector as augmented technology. Furthermore, in conducting a simulation on the closures of CGE, the model is the augmenting all factor technical change variable (a1prim) for the trade sector as augmented technology. This variable change is an exogenous variable that represents the use of technology. Where the sector is chosen in this simulation is the trade sector (Banerjee, 2015). An adaptation found that their recursive model produced similar price behavior in the energy sector and provided greater flexibility in the modeling framework.

The reason for using exogenous variables in this CGE model is prime as a variable that explains the technological change factor. As for the use of digital technology, it is obtained from changes in the use of technology in the trade sector each year, which is proxied based on the development of government and private budget allocations for information technology sector investment, especially in 
encouraging digitalization in the trade sector during the period 2014-2018. The change in figures per year becomes the numbers made for shock simulation. Where the average amount of each year in the range of $17.65 \%$. Proxy of investment magnitude as an allocation of the use of government and private spending in encouraging the use of information technology, especially digital technology (Minifie et al., 2017)

This figure is a number that explains the changes in the use of information technology, especially digital technology. Recursive-dynamic mode produces sequences of annual solutions connected by dynamic relationships such as physical capital accumulation (Adam et al., 2015). Then the number is used as a simulation number. In explaining the change in productivity, the simulation used is the exogenous variable technological change factor contained in the model. So the use of simulation figures becomes a proxy in explaining the improvement of information technology as an increase in digital technology in simulations in this analysis.

In order to explain the changes every year in the estimation period, using the CGE dynamic model. The simulation used is a dynamic CGE model; even the shock value is obtained from changes every year the amount of government and private expenditure in investing in information technology infrastructure from the period 20142018.

Simulation figures used as approaches to technology utilization in the trade sector are obtained from the average budget for infrastructure expenditure per year in the analysis period. The analysis period used is the 2014-2018 period, where the period is assumed to be the budget expenditure period for investment in information technology development. The government and the private sector issue both. It is hoped that this approach can represent the value of using information technology.

As previously explained, the simulation carried out, especially in the simulation process, investment as a proxy approach in calculating the simulation number. The amount of capital allocation represents the use or utilization of technology based on budget or capital because data is available and easily accessed as for the sector being simulated in the utilization of information technology. In this case, digital technology is the trade sector. 
It is expected that the simulation results will be able to answer the objectives of this study. However, the simulation figures used a proxy for budget or capital expenditure, to move and improve information technology, especially digital technology. Thus, the simulation results explain, and at the same time, give an overview of the impact of digital technology usage in the trade sector on the economy, especially on the indicators analyzed.

\section{RESULTS AND DISCUSSION}

The study used the dynamic CGE modeling analysis to investigate the impact of digital technology utilization on productivity, employment and economic growth in the next 15 years, namely 2018-2032. This dynamic CGE model provides an explanation that, in addition to predicting short-term and long-term, it also explains the trend of changes every year in the analysis period.

\section{The impact on its productivity}

The impact of digital technology utilization in the trade sector on its productivity is shown by the amount of output produced, as presented in Figure 1.

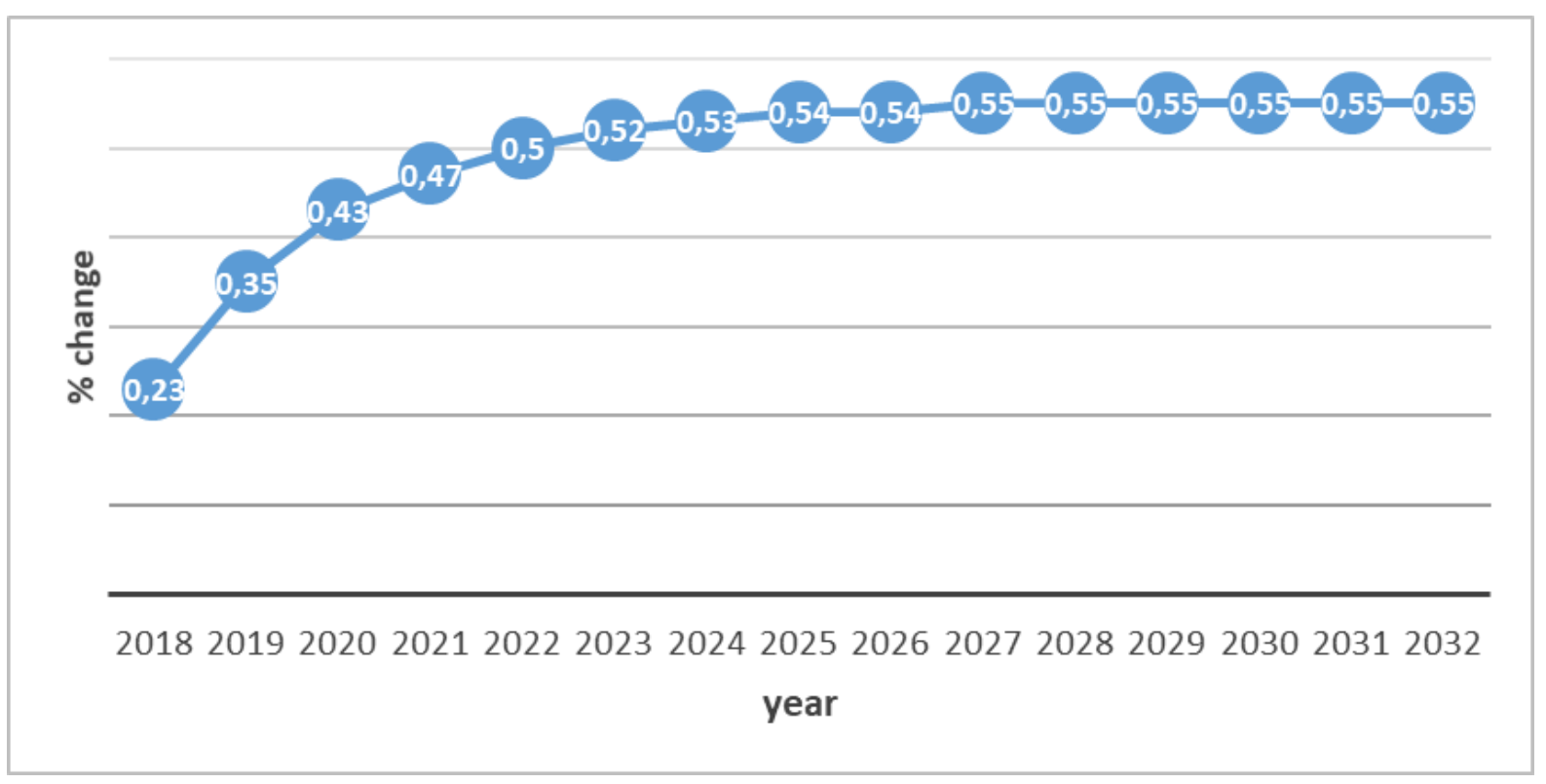

Figure 1. The Impact of Digital Technology Utilization in the Trade Sector on the Output Production

Source: CGE model result (2018), processed 
Figure 1. saw that the use of technology such as technology information in the trade sector would encourage output production in the sector. This means that the technology used in trade transactions contributed to increasing productivity in the trade sector itself.

Increased productivity occurs in the short and long-term periods, namely the analysis period for 15 years, namely in 2018-2032. During this period, it was seen that the use of digital technology in the trade sector provided an increase in the number of products produced.

In 2018, as a year of short-term analysis, the impact of using digital technology on the trade sector increased output by $0.23 \%$. It indicates that the amount of production as an indicator of the productivity of the trade sector in 2018 has increased by $0.23 \%$ due to the increasing use of information technology.

Figure 1. explain that the use of digital technology in the trade sector will drive the amount of output produced by the trade sector itself, which has an ever-increasing trend. This shows that information technology can provide an impetus for production. Digital technology is used in the trade sector as a production factor that will affect its output. Moreover, the current use of digital technology in the trade sector is increasing. This is consistent with the results of modeling. That digital technology in the trade sector has a positive impact on output in that sector.

The growing development of online shopping proves this, especially in selling various products. Online shopping is a trade that uses media information technology in the form of digital technology. Thus, the encouragement of digital technology will improve the total production of the trade sector itself.

In the next 15 years, the long-term period, where the condition of increased production in the trade sector increases output. In the long run, in 2032, the amount of output will increase by $0.55 \%$, beginning in 2027 .

Based on Figure 1, with the shortterm and long-term trends, it is seen that the analysis period 2018-2032 experienced a significant increase. It means that the impact of utilizing the trade sector digitalization technology, such as online trading, can boost trade sector's productivity by having an increasing trend every year.

This implies that digitalization will increase the trade sector's productivity, which is getting better and increasing. It 
means that the use of digital technology in the trade sector can raise production.

Thus, the increasing use of digital technology in the trade sector will increase production output from the trade sector, encouraging productivity in the trade sector every year in the analysis period. The impact is that the role of digital technology will further encourage trade productivity in the future. This has implications for increasing digital technology use in the trade sector through various digital technology stimuli for traders.

\section{The impact on the output prices}

In addition to the impact of this digitization on productivity, namely the increase in the amount of output, it also impacts the output price. The impact of using digital technology on the trade sector's output price is explained in Figure 2.

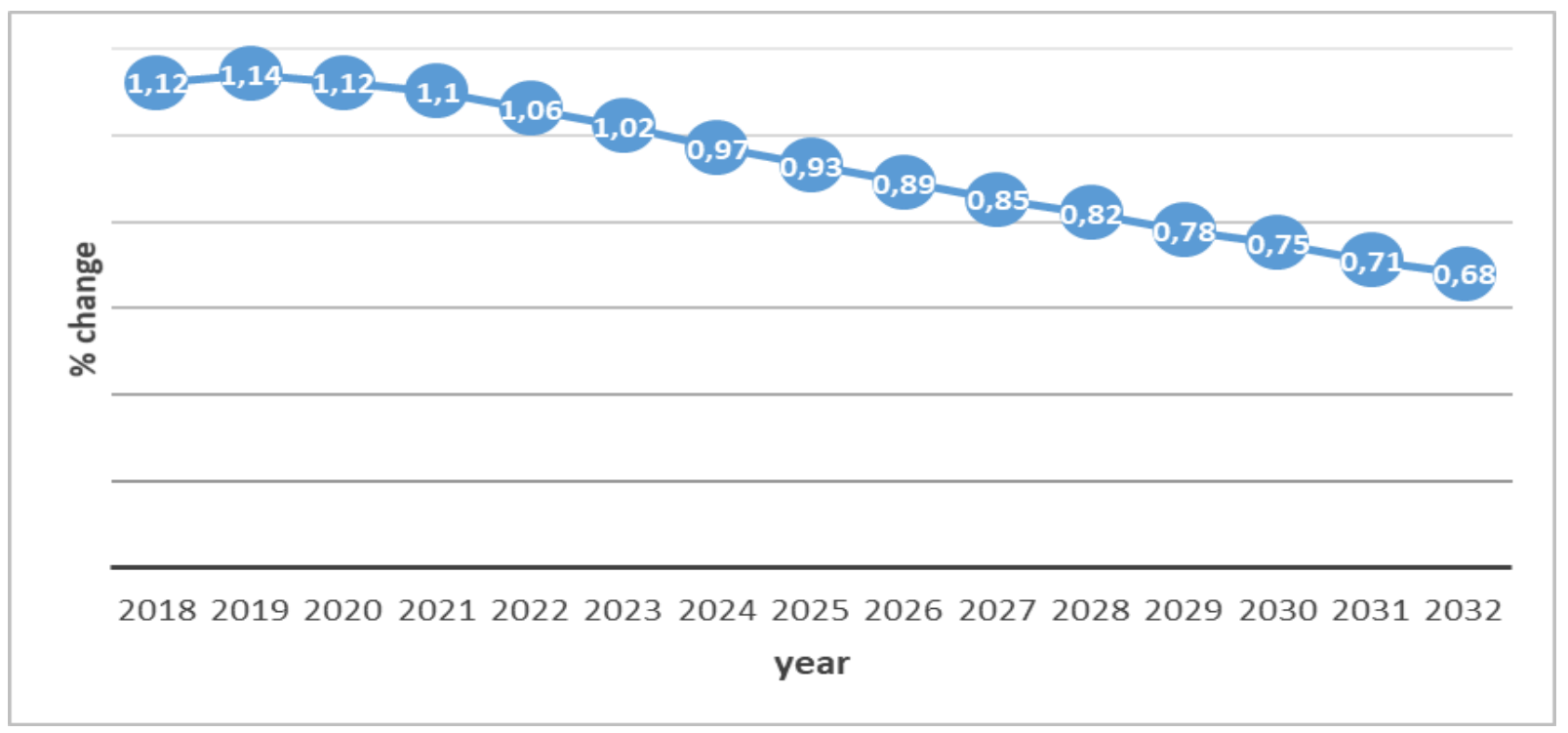

Figure 2. The Impact of Digital Technology Utilization in the Trade Sector on the Price of Gross Output

Source: CGE model result (2018), processed

Figure 2 shows that productivity increases occur in the short and long term periods, namely the analysis period of 15 years, 2018-2032. During this period, it was seen that the use of digital technology in the trade sector provided an increase in the output price. Increased productivity in the trade sector, where output rises, apparently has an impact on price increases. The price increase is due to the increasing number of requests for goods. This 
means that even though this trade sector's production output increases, the demand for goods also increases, and the equilibrium price that occurs is positive. However, the analysis period has a declining trend. During this period, each year has an increase where the percentage changes are increasing.

The impact of rising prices of goods in the trade sector shows that digital technology does not automatically reduce prices in its development. Price decreases occur periodically following changes in market price equilibrium because it is influenced by demand. Market balance adjustments occur periodically following changes in the price balance.

When viewed in 2018 , as a year of short-term analysis, the impact of using digital technology on the trade sector increases the price of its output by $1.12 \%$. This means that the price of output produced in the trade sector in 2018 has increased due to the amount of output produced, which increases only minimal.

This finding implies that the increase in output prices is caused by the higher demand for goods but not as high as the number of outputs produced in the same year of only $0.23 \%$. In other words, the output price for the trade sector increased due to increasing demand with the consumer price index in the same year increasing.

In the next 15 years, in 2032, the long-term period, where the impact of digitizing trade has increased the price of trade output. This means that in 2032 the output price increased by $0.68 \%$, decreasing value compared to 2018 . Trade digitalization encourages lower prices due to efficiency in trade transaction costs, such as warehouse costs, transportation costs, labor costs, maintenance costs, and tax costs. The trend has shown that in output prices, which is declining in the period 20182032. It means that the use of trade digitalization provides efficiency in transportation costs.

Thus, changes in the trend of output prices that declined during the analysis period indicate an adjustment in market equilibrium changes every year. The mechanism of falling price changes due to the demand for goods is still more than the total output generated in this trade sector. Changes in new equilibrium every year drive the price of equilibrium down due to a decrease in transportation includes the warehousing costs. 


\section{The impact on the labor}

This analysis can also see the impact using digital technology on the trade sector on its workforce absorption (Figure 3). Based on a short-term analysis, the impact of digital technology in the trade sector towards the absorption of labor in 2018 has decreased workers in the trade sector by $0.26 \%$. This condition shows that digitalization has led to the disruption of the workforce in the trade sector.

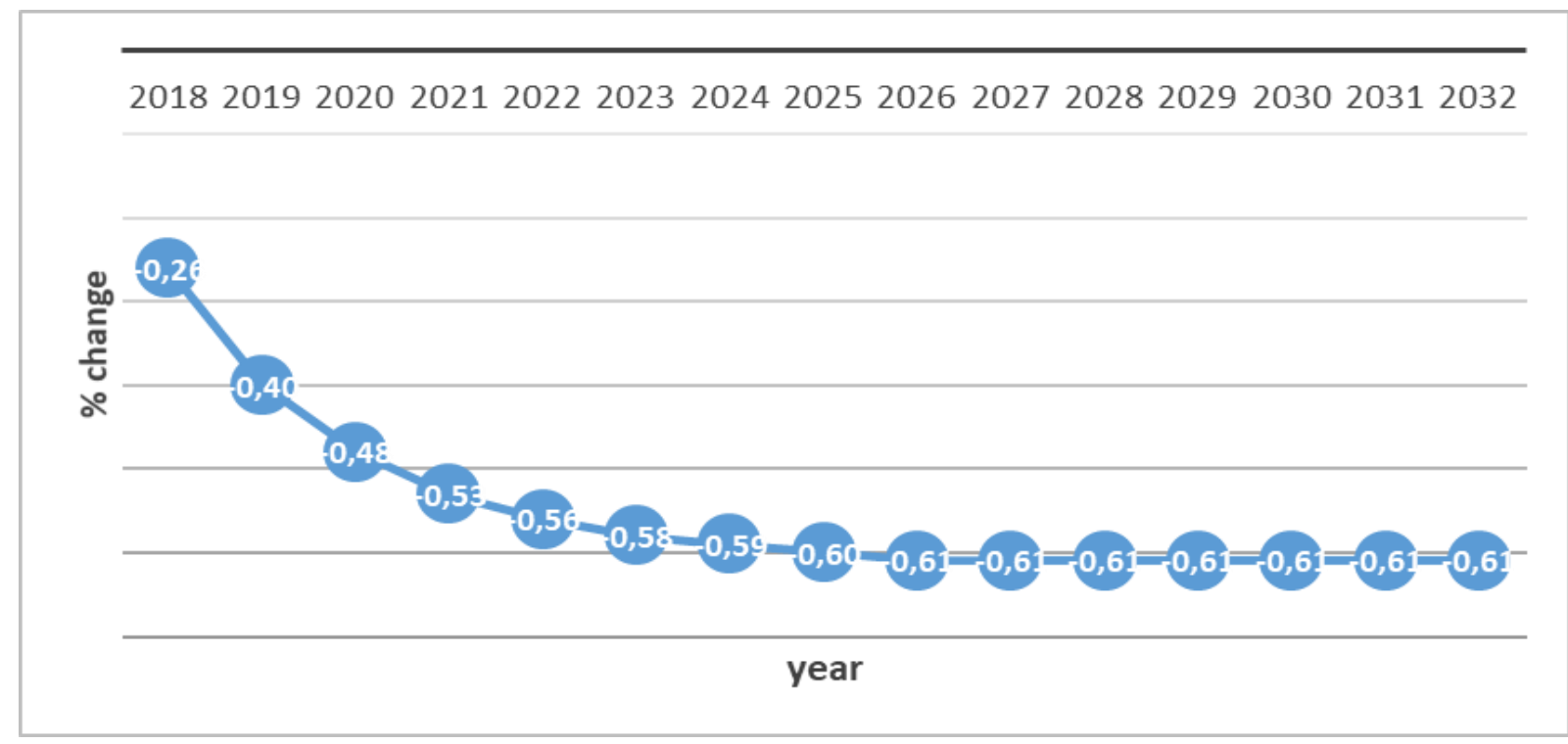

Figure 3. The Impact of -Digital Technology Utilization in the Trade Sector on the Labor Absorption

Source: CGE model result (2018), processed

The decline in the number of workers is caused by many transactions in the online trading system that erode the manual trading system. This change indicates that the disruption of various trading efforts due to online systems is disrupted. In addition to consumers who switch to online systems in transactions, there are also cuts in various transaction costs. As a result, the price of goods becomes cheaper by using an online system.

Likewise, in the next 15 years, in 2032, namely the long term, where the impact of trade digitization has decreased the amount of labor absorption by $0.6 \%$ of the actual. This means that in 2032 the number of workers employed in the trade sector will reduce by $0.6 \%$; the value is much 
higher than in 2018. This is because, in addition to lower prices, the efficiency of transactions is a consumer choice.

The impact of digital technology on the number of worker absorption in the 2018-2032 period has experienced a downward trend. There has been a disruption in several types of work in the trade sector (Figures 4 and 5).
Figure 4 describes the decline in the number of workers with type of work as the recipient of wages and salaries, administration, sales, and services of recipients of wages and salaries in cities and villages in 2018-2032. It ranges between $0.14 \%-0.33 \%$. It means that many workers have to move to other jobs besides that, especially for these types of worker.

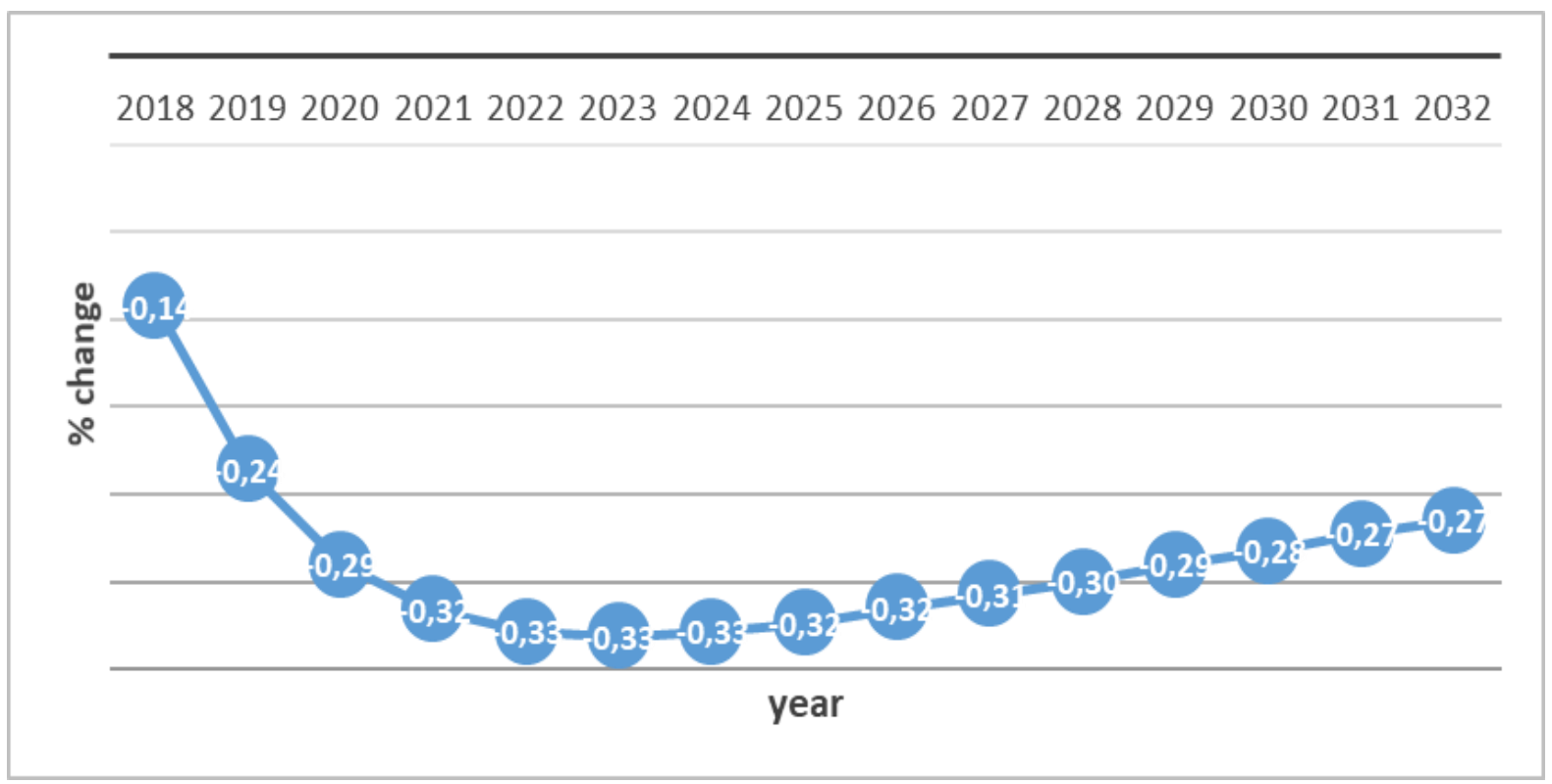

Figure 4. The Impact of Utilization of Digital Technology in the Trade Sector on the Type of Workers Receiving Wages and Salaries as Administration, Sales and Services of Recipients of Wages and Salaries In City-Villages

Source: CGE model result (2018), processed

The finding indicates that digital technology in the trade sector has pushed its move into this type of work. Companies in the trade sector consider this to be more efficient using digital technology. The most significant decline occurred in the period 2018-2022. Next, post-2022-2032, the trend is increasing.

Figure 5 explains the decreasing number of workers in the type of workers as operators, production, leadership, 
and professionals in city-villages in the period 2018-2032 with a range of $1.28 \%-0.68 \%$ where the magnitude of the impact is a decreasing trend. This means that many workers are not disrupted by other jobs in this type of work, even though they tend to decrease yearly.

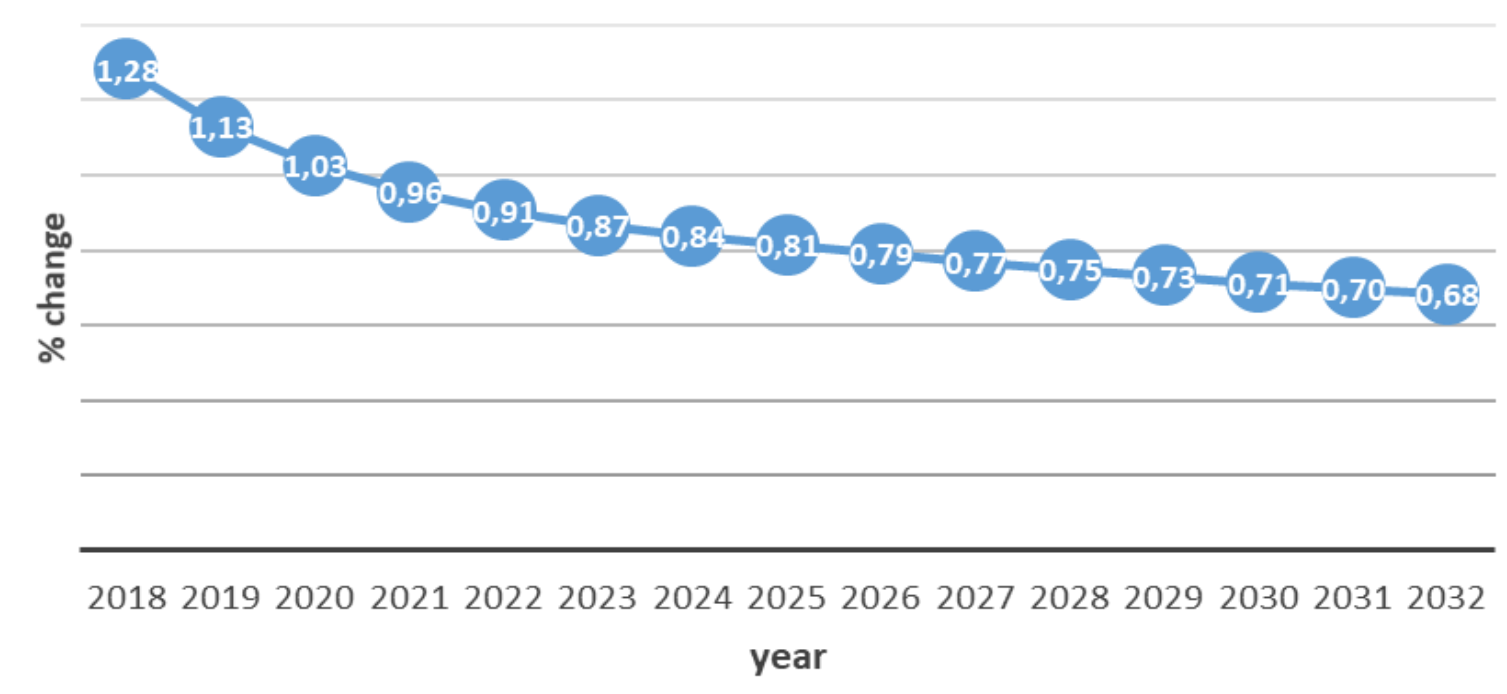

Figure 5. The Impact of Utilization of Digital Technology in the Trade Sector on the Type of Workforce as Operator, Production, Leadership and Professional in the City-Village

Source: CGE model result (2018), processed

Figure 5 shows that digital technology in the trade sector based on these types of workers in the short term does not encourage the transfer of other types of work, but in the long run, there is a decline. This means that in the long run, this type of work is significantly disrupted where the use of information technology will disrupt the workforce as a challenge in the future shifting employment on the type of workforce as the operator, production, leadership, and professionals in the city-village.
The impact on economic growth

The impact of using digital technology in the trade sector on national economic growth can be seen in Figure 6. This economic indicator growth is derived from the real GDP expenditure side. Economic growth in this study shows the process of changing a country's economy to a better state over a period analysis of 15 years, 2018-2032. Figure 6 explains that in the short term in 2018, the impact of digital technology utilization of the trade 


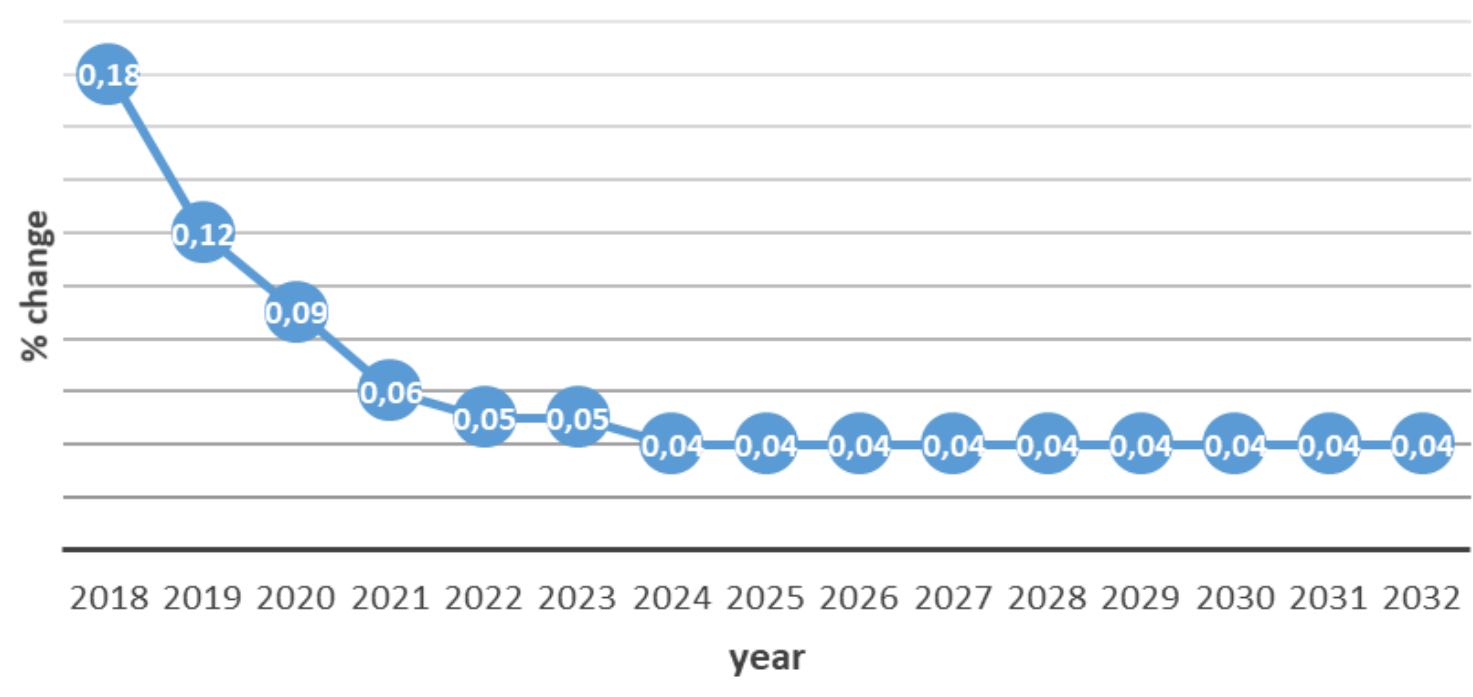

Figure 6. The Impact of Utilization of Digital Technology in the Trade Sector on Real GDP Growth

Source: CGE model result (2018), processed

sector on the increase in real GDP is very small equal to $0.18 \%$. This means that the digital utilization of technology in the trade sector can only contribute to real GDP of around $0.18 \%$ and not significant. It means so far; it still has not had a very good impact on economic growth. It is just that it has driven output growth at the sectoral level.

Furthermore, in the long run, namely the period 2018-2032, digital technology in the trade sector decreases, and its contribution to driving real GDP is only 0.04 percent. This means that the national economic growth formed is still minimal. Moreover, in this period, the trend of economic growth was decreasing.
By looking at these conditions, due to the digitalization of technology in the trade sector will be able to encourage national economic growth, the government needs to improve the accuracy and validity of database of competitive products, easy licensing services, optimization of digital technology applications in easier trade governance monitored, and improve information and technology infrastructure in the trade sector.

Thus, information technology, especially digital technology in the trade sector, will encourage trade transactions improvements. This includes domestic and foreign trade. Besides, it will encourage efficiency in transactions as 
well as in production. Of course, the better these transactions will encourage improvements in economic growth.

In addition, encouraging improvements in production technology in the trade sector will improve the trade sector's performance. It will also improve other macroeconomic indicators, such as improving the investment climate, household consumption, and government revenue because of the drive for demand and purchasing power of people towards prices that tend to decrease periodically. Therefore, digital technology, which is increasingly massive in its use in the trade sector, will encourage better economic growth.

\section{CONCLUSION AND POLICY RECOMMENDATION}

The conclusion drawn from this research is that the use of digital technology in the trade sector encourages its productivity to rise in the short and long term. As a result, the output price has trend decreased in the analysis period. The trend is the efficiency of post-production costs, such as warehousing costs, transportation costs, communication costs, and tax costs.
Also, the increasing use of digital technology will encourage a decrease in employment in the trade sector. This is proof that digital technology will disrupt the number of workers. This means that the drive to reduce employment in the trade sector shows the need for an anticipatory strategy to reduce rising unemployment. Facilitation and stimulus to open new jobs are the main things in responding to these changes.

Furthermore, the impact on the absorption of labor in the trade sector has decreased in the short and long term due to decreased worker type as the recipient of wages and salaries, administration, sales, and services of recipients of wages and salaries in both cities and villages.

Finally, the impact of digital technology in the trade sector increases real GDP, both short and long term, with a declining growth trend. This is because the increasingly massive use of digital technology will encourage businesses in the trade sector. In the end, it creates low-cost transactions and creates a better investment climate in the trade sector. Also, the trade balance has improved in numbers. Additionally, it encourages the people's purchasing 
power is increasing due to the downward trend in the price of goods in the long run. Thus, the increasing use of digital technology in the trade sector will encourage people's purchasing power.

Based on these conclusions that the use of information technology, especially government as a regulator, that the digital technology should be encouraged and expanded its reach, providing stimulus in accessing the reach of the technology to rural traders, e-commerce and online shopping, especially products produced by small and medium-sized enterprises (SMEs). In addition, by encouraging the strengthening of digital technology by strengthening technological innovation's power by businesses' needs in the trade sector.

Additionally, we suggest that the government improve the accuracy and validity of the database of competitive trade products and anticipate labor policies regarding occupation types that are disrupted immediately. The need to push licensing services that are increasingly facilitated in accessibility, optimize digital technology applications in trade governance, and fast improvements and utilization of information and technology infrastructure facilities on the trade sector.

\section{ACKNOWLEDMENT}

I would like to thank to the Director of Institute for Development of Economic and Finance (INDEF), Dr. Enny Sri Hartati, who has given us the opportunity to develop this CGE analysis model for using the policies analysis. In addition for Prof. Rina Oktaviani (the deceased) and Dr. Dedi Budiman Hakim who has been tutors to teach many aspects about CGE modelling such as concepting, calculating, modeling, writing and inspirating when completing master's and doctoral's program in Post Graduate School at Bogor Agricultural University.

\section{REFERENCES}

Adams, P., J. Dixon \& M. Horridge (2015), The Victoria Regional Model (VURM): Technical Documentation, 1.0. CoPS/IMPACT Working Paper No. G254, Centre of Policy Studies, Victoria University, Melbourne

Ahmdeov, I. (2020). The Impact of Digital Economy on International Trade. European Journal of Business and Management Research 5(4):1-7.

Azmeh, S., Foster, C.G., \& Echavarri, J. (2019). The International Trade Regime and The Quest for Free Digital Trade. International Studies Review 2(3): 671-692.

Baldwin, R. (2016) The Great Convergence: Information Technology and the New Globalization. The Belknap Press of Harvard University Press, Cambridge. 
Banerjee, Shweta S. (2015). From Cash to Digital Transfers in India: The Story So Far. CGAP Brief Consultative Group to Assist the Poor (CGAP), Washington,DC.

BPS. (2010). Sistem Neraca Sosial Ekonomi Indonesia 2008. Jakarta: Badan Pusat Statistik.

BPS. (2015). Tabel Input-Output Indonesia 2010. Jakarta: Badan Pusat Statistik.

Dixon, J., \& Nassios, J. (2016). Modelling the Impacts of a Cut to Company Tax in Australia. Centre of Policy Studies Working Paper G-260.

Dixon, J., \& Nassios, J. (2018). The Effectiveness of Investment Stimulus in Australia. Centre of Policy Studies Working Paper G-282.

Dixon, P.B. \& M.T. Rimmer (2005), "Explaining a dynamic CGE simulation with a trade-focused backof-the-envelope analysis: the effects of eCommerce on Australia", 3 Chapter 10, pp. 223-256 in S. Jayasuriya (ed.), Trade Theory, Analytical Models and Development: Essays in Honour of Peter Lloyd, Volume 1, Edward Elgar, U.K.

Dixon, P.B. \& M.T. Rimmer (2016), Johansen's legacy to CGE modelling: originator and guiding light for 50 years. Journal of Policy Modeling, vol. 38(3), May-June 2016, pp. 421-35.

Dixon, P.B., M.T. Rimmer (2002), Dynamic General Equilibrium Modelling for Forecasting and Policy: a Practical Guide and Documentation of MONASH, Contributions to Economic Analysis 256, North-Holland Publishing Company, pp. xiv+338.

Dixon, P.B., M.T. Rimmer \& B.W. Roberts (2014). Restricting employment of low-paid immigrants: a general equilibrium assessment of the social welfare implications for legal U.S. wage-earners. Contemporary Economic Policy, vol. 32(3), pp. 63952.
Dixon, P.B., R.B. Koopman \& M.T. Rimmer. (2013). The MONASH style of CGE modeling: a framework for practical policy analysis, Chapter 2, pp. 23-102 in P.B. Dixon and D.W. Jorgenson (editors) Handbook of Computable General Equilibrium Modeling, Elsevier.

Freebairn, J. (2017). Opportunities and Challenges for CGE models in Analysing Taxation. Economic Papers 37 (1), pp. $17-29$.

Ghandi, S., Thota, B., Kuchembuck, R., \& Shwart, J. (2018). Demystifying Data Monetization. MIT Slowan Management Reviews, 1-9 (online November 27, 2018)

Giesecke, J. A., \& Madden, J. R. (2013). Regional Computable General Equilibrium Modelling. In P. B. Dixon, \& D. W. Jorgenson, Handbook of Computable General Equilibrium Modelling (pp. Vol 1A pp 379-470). Elsevier.

Goldfarb, A., and Tucker, C. (2019). Digital Economics. Journal of Economic Literature 2019, 57(1): 3-43.

Gryseel, M, Kaushik, D, Priyanka, S, \& Khoon, TT. (2016). Unlocking Indonesia's Digital Opprtunity. Indonesia: McKinsey\&Company.

Henry, G.S. (2018). Digital or Trade? The Contrasting Approaches of China and US to Digital Trade. Journal of International Economic Law (21): 297321.

Horridge, M. (2002). ORANIGRD: a Recursive Dynamic version of ORANIG.

Indonesian Internet Service Provider Association (APJII)., (2018). Penetrasi dan Profil Perilaku Pengguna Internet Indonesia. Survey Report, 2018.

Meng, S \& M. Siriwardana. (2017). Assesing the Economic Impact of Tourism: A Computable General Equilibrium Modelling Approach. 
Palgrave Macmillan. Switzerland: Springer International Publishing AG.

Minifie, J., Chisholm, C., \& Percival, L. (2017). Stagnation nation? Australian investment in a low growth world. Grattan Institute Report 2017-02.

Oktaviani, R. (2001). Implication of APEC Trade Liberalization and Other Changes for Indonesia Economy, Quarterly Review of the Indonesian Economy. Jurnal Bisnis dan Ekonomi Politik, 4(1): 2-43.

Osorio, BB., Sumitra, D., \& Bruno, L. (2014). The Global Information Technology Report 2014: Rewards and Risk of Big Data. Switzerland: World Economic Forum.

Parlindungan, M. (2015). The Internet User Profile 2014. Jakarta: Asosiasi Jasa Penyedia Internet Indonesia.

Ritter, T \& Pederson, C.L. (2020). Digitization Capability And The Digitalization Of Business Models In Business-To-Business Firms: Past, Present, And Future. Industrial Marketing Management 86(2020): 180-190.

Romer, D. (2011). Advanced Macroeconomics. Fourth Edition. Singapore: McGraw-Hill College Publishing.

Rose, A., F. Prager, Z. Chen \& S. Chatterjee (2017), Economic consequence analysis tool (E-CAT), Springer, Tokyo.

Ross, J. (2017). Don't Confuse Digital with Digitization. MIT Slowan Management Review (Online September 27, 2017).

Rowe, N. (1987). An Extreme Keynesian Macro-economic Model with Formal Micro-foundations. Canadian Journal of Economics, 20(2): 306-20.

Syam, N., \& Sharma, A. (2018). Waiting for a Sales Renaissance in the Fourth Industrial Revolution: Machine Learning and Artificial Intellegence in Sales Research and Practice.
Industrial Marketing Management 69(1): 135-146.

Taufikurohman, M.R. (2004). Dampak Peningkatan Produktivitas Pangan terhadap Kinerja Sektoral dan Ekonomi Makro Indonesia: Analisis Ekonomi Keseimbangan Umum. Tesis. Bogor: Sekolah Pascasarjana Institut Pertanian Bogor.

Taufikurohman, M.R. (2012). Dampak Kebijakan Fiskal pada Sektor Pertanian terhadap Ekonomi, Tenaga Kerja, Distribusi Pendapatan dan Kemiskinan. Disertasi. Bogor: Sekolah Pascasarjana Institut Pertanian Bogor.

Walmsley, T., C. Lakatos \& P. Minor (2015). Capital and labor substitution in Computable General Equilibrium Models. Working Paper 003, ImpactECON.

Wittwer, G. (1999). WAYANG: A General Equilibrium Model Adapted for the Indonesian Economy. Edition prepared for ACIAR Project no 9449. CIES University of Adelaide (in association with RSPAS, ANU, CASER, Bogor, and CSIS, Jakarta.

Wittwer, G. (2017), Multi-regional dynamic general equilibrium modelling of the U.S. economy: USAGE-TEM development and applications, Springer, Switzerland, pp. xiv+236.

Yadiati, W \& Meiryani. (2019). The Role of Information Technology In Ecommerce. International Journal of Scientific \& Technology Research 8(01): 173-176.

Zahniser, S. T. Hertz, P.B. Dixon \& M.T. Rimmer. (2012). Immigration Policy and its Possible Effects on U.S. Agriculture and the Market for Hired Farm Labor: a simulation analysis. American Journal of Agricultural Economics, Vol. 94(2), January, pp. 477-82. 